\title{
A Study on the Figurative Universality of Religious Costume -Centering on the Religious Costume of High Religions-
}

\author{
Bong-Ha Seo \\ Dept. of Stylist, Yong-in Songdam College \\ Received April 27, 2009; Revised May 19, 2009; Accepted May 20, 2009

\section{종교복식의 조형적 보편성에 관한 연구 \\ -고등종교의 종교복식을 중심으로-} \\ 서 봉 하 ${ }^{\dagger}$ \\ 용인송담대학 스타일리스트과 \\ 접수일(2009년 4월 27일), 수정일(2009년 5월 19일), 게재확정일(2009년 5월 20일)
}

\begin{abstract}
Just as various religions of the world have multiple systems based on their own belief system respectively, religious costumes, which are the expression of religion, are varied in forms according to different religions. Nonetheless, this research attempts to examine the universal features of the variety of religious costumes. Since the range of this research is broad and the limit of study is clear, this research confines the study objects into world's four high religions. The purposes of this research are as followings; first, the investigation of the world's high religions, second, the study of the figurative attributes of religious costume to study and discuss the universality of figurative beauty and aesthetic value. Figurative attributes are distinct in religious costume. First, the non structural feature of composition, and the manner in which the costume is worn. Second, the rich silhouette covering the body. Third, the restraint and inhibition of decoration, and fourth, the preference of achromatic color and monotones. 'The beauty of concealing', derived from the religious absolute and chastity, 'The beauty of chastity' influenced by the restraint of decoration and design, and 'The beauty of nature' as the drapery and non structural feature are the universal aesthetic values. Human beings tend to contact the divine beings by pursuing the essential thing and concealing the body through religion. The forms of concealment and chastity, mentioned above are reflected in the usual costumes, affected by religion as well as religious costume.
\end{abstract}

Key words: Religious costume, World's high religion, The beauty of concealing, The beauty of chastity, The beauty of Nature; 종교복식, 세계 고등종교, 감춤의 미, 절제의 미, 자연의 미

\section{Introduction}

Religion is one of universal cultures in human society and religious belief about the transcendental power which is perceived to have an effect on human life and the beliefs about being are expressed in spe-

${ }^{\dagger}$ Corresponding author

E-mail: cartrip@naver.com cific forms of belief and rite. The belief system of each religion understands the world through symbols and induces action through these symbol. Religious rite is the symbolic action, expressing the religious meaning and practices it. Formality and rituals are weighted than the purpose of religious practice. All life and events around us are filled with such symbolic meaning, and it is applied to the case of costume. 
Religious costume embodies religious belief system as a particular existence form and symbolizes it. Generally, reverend costume that shows the distinctive purpose, visualizing religious meaning and value is considered to be religious costume. However, in the case of Islam, ordinary pilgrims wear religious costume because Islamic clerics do not exist in principle. Religious costume tends to have an effect on the ordinary people's costume.

Just as religions around the world show diverse forms on the basis of individual belief systems, structure, history, and environment, religious costume that is the expression of religious meaning and symbolic action is varied in form according to the uniqueness of individual religion. However, this research puts purpose in exploring general features of the variety of religious costume. Since the range of religions of the world is vast and indistinct, the limit of study is inevitable. This research confines the study objects into four worldwide high religions; Buddhism, Hinduism, Islam, and Christianity in consideration of the development level of a religious system, history, the number of believers and distribution regions.

This thesis that is primarily based on the literatures is differentiated from existing studies in the aspect that it studies the universality of several religious costumes rather than focusing on a separate religion and it arouses the discussion about religious features, expressed through costume by exploring the universality of religious costumes, revealing religious beliefs and symbols. The purposes of this research are as followings. First, it examines the belief systems and features of religion, secondly, it studies the figurative attributes of religious costume, thirdly, it arouses the discussion of universal figurative beauty and aesthetic value of religious costume.

\section{Religion of the World}

\section{The Definition of Religion}

Since the fear of nature and the unknown world changed into awe and formed religious idea, religion has settled as one of universal cultures in human society. Religious belief is expressed in specific forms of faith and rite. Therefore, religion plays an essential part in understanding the life pattern and culture system of a group and community.

Religion is the intricate notion to define because people have different views about religion. There are many religious systems such as Judaism, Christianity, and Islam that postulate the existence of absolute and personified God, Buddhism and Hinduism that do not admit the single and only God, Confucianism and Taoism that have the philosophical features, and even Shamanism and Totemism.

Even though numerous religious scholars define religion differently, the definition of religion through theoretical exploration of religion has common features as followings. Firstly, Religion is the recognition of other supernatural world, based on the faith of being or beings of disparate world. Secondly, it is ritual actions like measures or procedures for fulfilling people's wish for the ideal and new life under the supernatural power of other being or beings (Park. 2008). Numerous theories define religion under the premise of absolute being, explaining that religion is 'human conviction about transcendental power and action'. However, this kind of definition is west Christianity centrism, and preconceived idea.

\section{Religion and Costume}

Religion is formed through action as well as representation. Rite is the practice of religious meaning, the action of religious symbol, and the method for salvation. These meanings are religiously ritualized by going through focusing, framing, and displaying. Ritual is largely divided into Imitation rite, Positive or Negative rite, Sacrificial ritual, and Passage rite. Religious costume or costumes that are affected by religion are the manifestation of these ritual actions. It is same as religious rites that are expressed with a memorial service, festival, prayer, construction, art, music, and so on. This kind of performance art or figurative art contains religious meaning and the action itself such as participating, practicing, painting, singing, and wearing costume is a way of salvation (Seo \& Kim, 2007).

Costume is the devotion towards the body and a 
kind of belief. Spiritual identity that dominates religious image is originated from religious commitment and custom. The systematic efforts through transcendental life have religious style art. Religious rites such as Imitation rite, Positive or Negative rite, Sacrificial ritual, and Passage rite are expressed in religious music and formative art and also manifested through costume that can be seen as a field of figurative art (Seo \& Kim, 2007). Religion has had the dominant effect on the whole culture of human beings including costumes as a belief system, illuminating the meaning of new life.

\section{High Religion of the World}

Numerous religions including folk religion in accordance with the environment and culture have existed. It is possible to classify the religions that have risen and fallen together with human beings and human history, and furthermore, religion is largely divided into Primitive religion and High religion. While Primitive religion based on favor seeking animism and shamanism believes that the soul is imbedded in all things of nature, High religion believes invisible thing. Accordingly, High religion put its basis on the invisible and unknowable thing (Yang, 2008).

High religions have been distributed to extensive regions by transcending races and nations and their founders are clearly known and their sanctuaries are equipped (Yamaori, 2000/2004). High religions are clas- sified into three groups according to the site of origin. Judaism, Christianity, Islam are God centered religions that were emerged from the dry land of Southwest Asia while Hinduism, Buddhism, Baha, Jainism, Sikhism are philosophical and human centered religions that came from the hot and humid India. The origins of Taoism, Confucianism, and Shintoism are East Asia. The religions of dry land are purposeful and world change oriented, while the religions of India are meditative and acquiescent. The Far East religions are concerned about the harmony in nature and the universe (Fallding, 1974).

Especially, world's high religions that represent the large scaled and advanced religion along with a long history, are generally narrowed to four religions: Christianity, Islam, Hinduism, and Buddhism. The believers of these four religions are $71.1 \%$ of the world population and accounts for $84.6 \%$ of world religions' population. The study of objects about the world religion cannot confine its range in consideration of the peculiarity of religion, and its limit is distinctive in the effectiveness. Therefore, this research targets at four high religions, <Table $1>$ is the distribution of world religions' population based on the statistics of adherents.com.

\section{Figurative Features of Religious Cos- tume}

Since the costumes, worn by clergyman of particu-

Table 1. The distribution of world religions' population

\begin{tabular}{c|c|c|c}
\hline \hline Religion & $\begin{array}{c}\text { Percentage compared to } \\
\text { the world population }\end{array}$ & Major sects and religions & Major distribution area \\
\hline Christianity & $30.6 \%$ & $\begin{array}{c}\text { Catholic, Protestantism, } \\
\text { Eastern orthodox, The Anglican domain }\end{array}$ & North America, Europe, worldwide \\
\hline Islam & $21.9 \%$ & Sunni, Shiah, Sufism & Asia, Africa, Europe \\
\hline Hinduism & $13.1 \%$ & Vishnu, Siva & Africa Nepal \\
\hline Primal-indigenous & $5.8 \%$ & $\begin{array}{c}\text { primal-indigenous, } \\
\text { African Traditional \& Diasporic }\end{array}$ & China, East Asia \\
\hline Chinese religion & $5.7 \%$ & Confucianism, Taoism & Northeast Asia, Southeast Asia \\
\hline Buddhism & $5.5 \%$ & Mahayana, Hinayana, Lamaism & Sikhism, Judaism, Bahaism, \\
\hline Other religions & $1.4 \%$ & Secular, Agnostic, Atheist & \\
\hline Nonreligious & $16.0 \%$ & &
\end{tabular}


lar religions reveal the distinctive purposes to demonstrate the religious meaning and value visually, the costume itself implies religious meaning and cue and symbolizes status, elegance, the sacredness of a ritual, and the role of an individual, position, and circumstance in the religious group (Kim, 1993). Especially, religious costume is the costume of a religious person, used in the religious ceremony, in which belief system is embodied in the body as a particular being mode.

On the account that religious costume contains the mentality of doctrine compared to the general costume its use is not popularized and unsocial (Lim. 1990). Therefore, it has continued to exist according to the regulation and restraints of particular costume and institutional features of religious costume have had an effect on the costumes of common people. Chapter III investigates the figurative attributes of religious costumes of world four high religions.

\section{The Religious Costume of Buddhism}

Buddhism maintains that nothing in the universe is permanent and unchanged so that the core of the universe is emptiness. Liberation called the 'Nirvana' is possible when man understands the true nature of void and transient thing (Smart, 1983). Accordingly, Buddhism is said to be a philosophical religion for the enlightenment. The eastern Aesthetics has received a lot of aesthetical concepts from the Buddhist thinking (Yun, 1993), and key ideas that had an effect on the aesthetics are non-duality, emptiness, five elements, and a way to use mind.

Buddhism costumes that are inclusive of monk's robe do not disclose the body in a state of not taking the form and are strongly related to the form of costume, covering the full body. The monk's robes are clean clothes that are not tinted, and frugal (Kim, 2002). The robe of <Fig. 1> is the rich form with front open dress, and $\langle$ Fig. 2$\rangle-<$ Fig. 3$\rangle$ are the forms that cover the body with cloth. All robes are single color such as gray, orange, and thick red, and decoration is not found.

The figurative forms of Buddhist costume have some features; first, no structure and no form with just wrapping the body, second, opulent silhouette of natural drapery, third, non decoration with the norm of chastity and modesty, and fourth, unmanifested form, The mentality of unmanifested form is expressed with inartificial color, gray, orange, and dark red. Like this, Non structural costume valuing much of total seeming beauty with the opulent silhouette based on the religious idea has been developed in Buddhism costume, which has features of the expression of unmanifested form and the inhibition of decoration.

'The beauty of the void' 'The beauty of concealing' and 'The beauty of nature' appear in the Buddhist costume. The beauty of the void appears in the formless costume that doesn't take any form and the non-decorative costume, which is the world of the emptiness making things clear for the exchange with

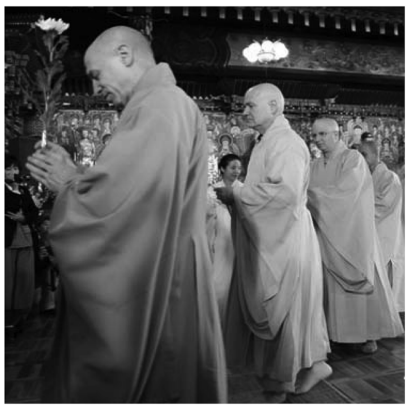

Fig. 1. Tea making Ritual to the memory of a deceased monk in the Korean temple.

Retrieved from http://www.bulgyotoday. com/

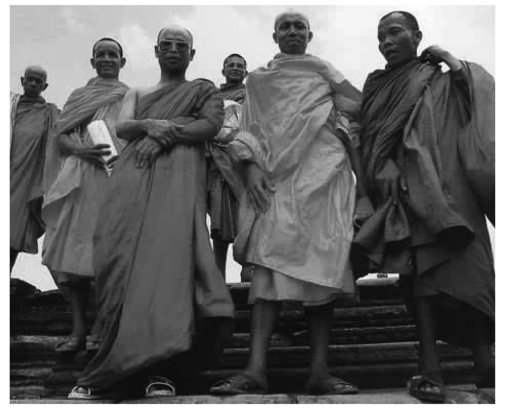

Fig. 2. Monks of Cambodia, wearing the orange robe.

Retrieved from http://www.angkor-wat-net.com/

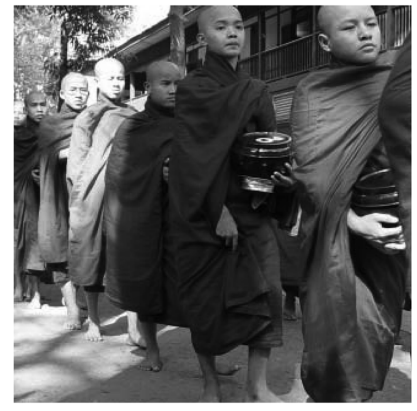

Fig. 3. Lunch food offering in the Buddhist temple in Myanmar.

Photographed by author (Feb. 16, 2007) 
the universe. The beauty of concealing is seen from non structural form and whole rich costumes, concealing the body with drapery. These costumes that cover and conceal the body have the features of closedness and clarity. The beauty of nature is shown in the non structural and asymmetric changeability of drapery and the color that preserves the color of nature.

\section{Religious Costume of Hinduism}

Hindu costume symbolized the belief system of religion in its formation process with certain styles of costume. The masters and disciples of Hinduism; Guru, Yogi, and saints wear Dhoti which is unstitched cloth worn like a pair of pants with a cloth placed over the left shoulder and the half of the body. Gurus and Brahmans who officiate the holy ceremony wear Dhoti made of white silk, and throw on the sacred thread from the left shoulder to the right waist, which means a spiritually reborn person, representing the combination with the absolute, which is the source of all beings as well as the unity of the experiential world and transcendental world (Kwon \& Cho, 1997).

There are fundamentals of the Hindu costume in terms of the principle of cleanness and uncleanness (Leslie, 1992). The costumes made of silk and wool are permanently pure. Cloth that remain unstitched is seen as purer than that which has been stitched. Hindu priest wears unstitched clothes while he presides over a rite. The unstitched clothes are pure on the naked body (Cho, 2005), and white, yellow, and red are recognized as sacred colors. While the <Fig. $4>$ is the figure of a Hindu priest who wears the red turban, sacred white chadar, and the Dhoti, <Fig. 5> are the figures of Hindu priests who officiates Puja ceremony, all of whom wear Dhoti and sacred thread. <Fig. 6> is the figure of a guru, who is performing the ritual of Puja.

The figurative attributes of Hindu costume are as followings; first, the opulence of unstitched natural drapery, second, the decoration and embellishment of various symbols, third, white, yellow, and red symbol. The wearing method that covers the body with a piece of cloth, wraps, and veils makes Hindu costume non-systematical, drapery, and open.

The aesthetic values of Hindu costume are 'The beauty of nature', 'The beauty of concealing', and 'The beauty of chastity'. The unstitched clothes, worn by Hindu priests are non-systematical and show the beauty of nature from the unsymmetrical drapery. While the beauty of concealing from the form, wrapping the body and the beauty of the chastity from the limited decoration and sacredness appear.

\section{The Religious Costume of the Islam}

The costume, wrapping the whole body of Islam, is the means to protect the body from poor nature environment but currently, it has been settled as a tradition of Islam by being absorbed in the Islam (Ross, 1985). As time passed, such tradition was solidified

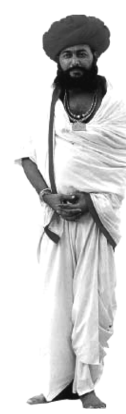

Fig. 4. Hindu Priest.

From Bhandari V. (2004). Costume, textiles and Jewellert of India. p. 105.

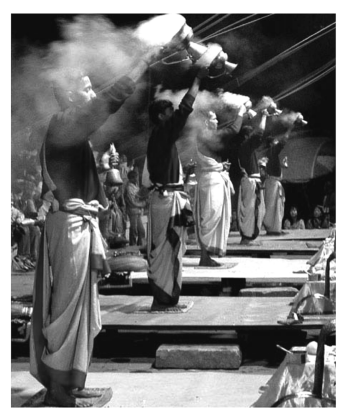

Fig. 5. Puja ceremony of the Ganges.

Photographed by author (Jan. 21, 2005.)

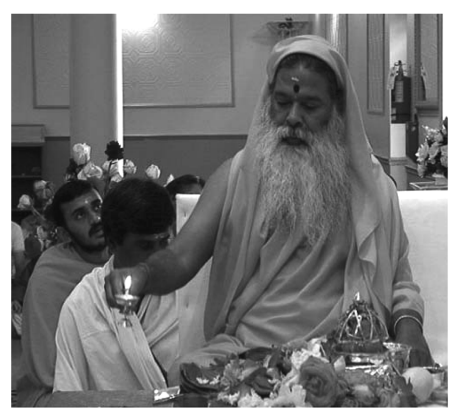

Fig. 6. Shani Puja on Shani Trayodashi day.

Retrieved from http://dattapeetham.com/ 
to be the Islam costume and has been reinforced according to some religious systems and social norms based on the interpretation of the Koran, which is the scripture of Islam. Priests are not officially authorized in Islam, and lawyers called 'sheikh' play a role of clergyman.

When even ordinary people as well as Sheikh who make a pilgrimage to the Mecca according to the equality idea of Islam wrap the white cloth evenly on the naked body. The Ihram, made of two pieces of cloth that is unstitched is the most Islamic costume. $<$ Fig. $7>-<$ Fig. $8>$ are white Ihrams which are pilgrimage clothes in the Islam tradition, and <Fig. 9> is the figure of Sheikh, throwing Abba over the Jubbah, long outer garment that opens in front.

The figurative attributes of Islamic costume are as followings; first, the non structural drapery costume, wrapping the body with the formlessness, second, the long and rich clothing style, covering the whole body, which is caused by dry and humid nature environment, third, the costume structure, which is characteristic of closedness and wholeness, and fourth, the moderate decoration and color of Islam costume. Islamic costume regulations and Islam fundamentalism based on the 'Koran' have succeeded to the tradition of Islamic costume. The control of the body and strong closedness are applied to the ordinary people's costume as well as a woman's dress.

The chief aesthetic values of Islam costume are 'The beauty of concealing', 'The beauty of chastity', and 'The beauty of nature'. While the beauty of con- cealing was originated from the form of traditional costume and the strict control of the body under the effect of nature environment, the beauty of chastity is reflected in the monotonous structure of Islamic costume and silhouette, non-decoration, and white monotone. The beauty of nature is expressed in the formlessness and non structure through wearing the Ihram clothes and having natural drapery.

\section{The Religious Costume of Christianity}

Protestantism denied the clerical clothing because protestants had the intention to clear the old frame after religious reformation. The catholic that has the lengthy tradition conferred the distinctive symbolic meaning on the religious costume within the church compared to other religions. The vestments of the Catholic and the Greek Orthodox Church reveal the symbolic meaning of a uniform and represent the dignity and respect. In other words, religious clothes play a role in approaching God by helping the connections between God and human beings giving the sacred atmosphere arousing the solemn and pious respect (Kim et al., 1999). Vestment of Catholic priest expresses the joy and sadness of religious ceremony itself through symbols and colors, which play the role of arousing the psychological sympathy towards participants in the service, and performs the function to ruminate and reinforce the religious idea when priest wears it (Kim et al., 1999). <Fig. 10> are bishops, including pope Joannes Paulus II and Cardinal

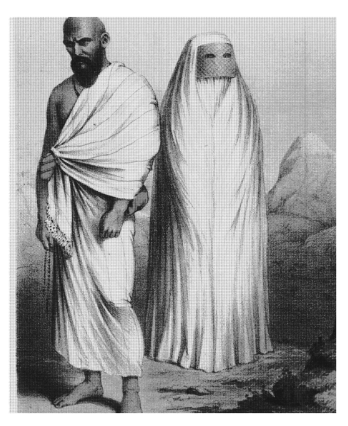

Fig. 7. Ihrams which are pilgrimage clothes in the Islam tradition.

Retrieved from http://en.wikisource.org/

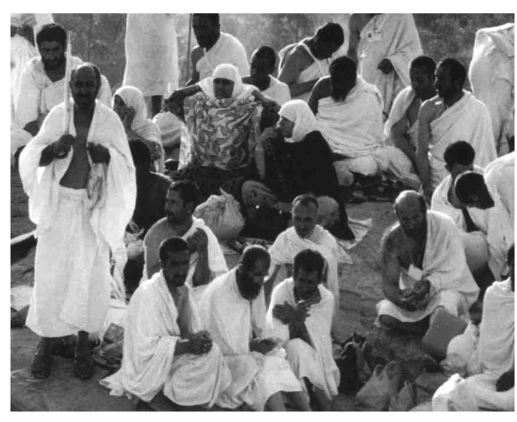

Fig. 8. Mecca pilgrimage, wearing Ihram. From Smith, H., Tickle, P., Armstrong, K., \& Gattuso, J. (2006). Talking to God: Portrait of a world at prayer. p. 150.

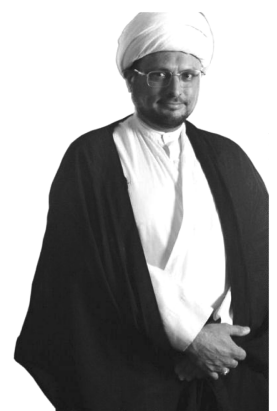

Fig. 9. Throwing abba over Jubbah.

Retrieved from http://smma59. wordpress.com/ 


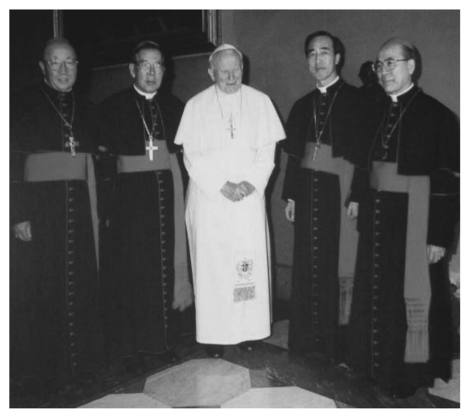

Fig. 10. Korean bishops, and pope who wear the white Soutane and black Soutane.

From The Korea Church history institute. (2001). Kim Su Hwan. p. 260.

Kim, Su-hwan, who respectively wear the white Soutane and black Soutane. <Fig. 11> is the ordination scene of the religious service of Catholic priest, and $<$ Fig. 12> is the shape of the orthodox church's priest in which comparatively gay decoration is seen.

The figurative attributes of the Christianity are as followings; first, the long one piece, covering the full body for emphasizing the verticality, second, the form of some layered items such as one piece, gown, manteau, and shawl, third, the variety of religious decorations and symbolism of pattern including the cross, and fourth, the colors of religious sacredness such as white, black, ivory, yellow, and so on.

'The beauty of the solemnity', 'The beauty of concealing', and 'The beauty of chastity' are indicated in this kind of Christianity costume. Religious beauty of solemnity appear in the closed silhouette, emphasizing the verticality as well as decoration and color. 'The beauty of concealing' in the form of costume, completely wrapping the body not to reveal the body is an expression of awe towards the absolute God. 'The beauty of a chastity' is expressed in the limited decoration and pattern of religious symbol and color.

\section{The Figurative Beauty of Religious Costume}

\section{The Figurative Beauty of Religious Costume}

The religious costumes of the world four high religions have a variety of figurative attributes that are

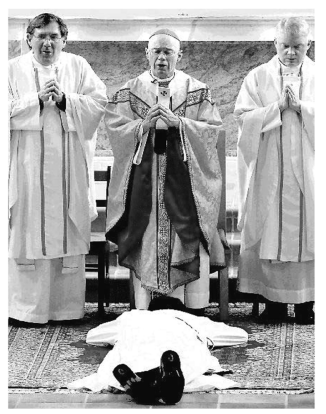

Fig. 11. The ordination scene of the religious service of Catholic priest.

etrieved from http://canada.com/

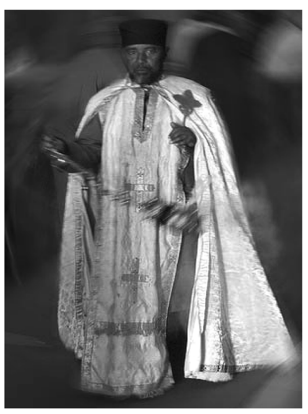

Fig. 12. Soutane of the orthodox church's priest.

Retrieved from http://flickr.com/ influenced by different belief systems and environment. Buddhist costume has the affluent silhouette, not revealing the body, single colors such as gray and red are used and decoration is restrained. Non structural unstitched clothes based on the cosmology of Hinduism are unique with symbols such as white, yellow, and red appearing. While Islam costume, emphasizing chastity has the concealed and closed form, the religious costume of the Catholic expresses the beauty of solemnity by emphasizing the verticality, appointing the symbolic meaning of rank through the decoration and color.

In spite of the difference in the formality of the religious costume of world's four high religions, figurative universality exists in the following ways. First, there is the non structural feature in the composition, form, and wearing method of clothing appear in all religious costumes. Unstitched cloth of formlessness are equally seen in the costumes of Buddhism, Hinduism, and Islam. Second, rich silhouette with drapery, covering the body is seen. It is represented mostly with the one-piece costume of Buddhism, Islam, and Christianity. Third, religious decoration and design appear in a very limited way compared to the ordinary costumes, however decorations rarely appear, especially in the religious costumes of Buddhism and Islam. Fourth, the preference of achromatic color and mono ton that implies the solemnness and sacredness are found.

This kind of monotonous costume forms have the silhouette of wholeness type in which the whole is 
Table 2. The particularity and universality of world 4 religions' costume

\begin{tabular}{|c|c|c|c|c|}
\hline Item Religion & Buddhist costume & Hindu costume & Islam costume & Christian costume \\
\hline $\begin{array}{l}\text { Structural } \\
\text { Features }\end{array}$ & $\begin{array}{l}\text { - Rich silhouette, wrapping } \\
\text { the body } \\
\text { - The costume of non } \\
\text { structural and natural } \\
\text { beauty by placing the } \\
\text { weight on the total } \\
\text { beauty of appearance }\end{array}$ & $\begin{array}{l}\text { - Nonstructural costume, } \\
\text { covering the body as } \\
\text { unstitched costume } \\
\text { - Natural drapery }\end{array}$ & $\begin{array}{l}\text { - Rich silhouette covering } \\
\text { the body with a large } \\
\text { cloth } \\
\text { - Natural drapery }\end{array}$ & $\begin{array}{l}\text { - Emphasis on the } \\
\text { bilateral symmetry and } \\
\text { verticality } \\
\text { - Rich and natural } \\
\text { one-piece type, covering } \\
\text { the whole body }\end{array}$ \\
\hline Color & $\begin{array}{l}\text { Inartificial color, gray, } \\
\text { orange, red, etc }\end{array}$ & $\begin{array}{l}\text { White, yellow, and red } \\
\text { that implies the sacred } \\
\text { attributes }\end{array}$ & $\begin{array}{l}\text { White of fidelity and } \\
\text { rigorousness }\end{array}$ & $\begin{array}{l}\text { White, black, and } \\
\text { so on for the absolute and } \\
\text { solemnity }\end{array}$ \\
\hline Decoration & The restraint of decoration & $\begin{array}{l}\text { Limited decoration such as } \\
\text { Sacred thread and Sindhu }\end{array}$ & The restraint of decoration & $\begin{array}{l}\text { Limited decoration } \\
\text { expressing religious } \\
\text { sacredness }\end{array}$ \\
\hline \multicolumn{5}{|c|}{$\downarrow$} \\
\hline $\begin{array}{l}\text { Universal } \\
\text { Features }\end{array}$ & \multicolumn{4}{|c|}{$\begin{array}{l}\text { - The silhouette covering the body } \\
\text { - Natural drapery } \\
\text { - Dull color; white, black, yellow, etc } \\
\text { - The restraint of decoration } \\
\text { - Whole type in which costume is recognized as one } \\
\text { - Plane figure with plainness and the silhouette with clarity }\end{array}$} \\
\hline
\end{tabular}

recognized as one, in which the silhouette of a plane figure and clarity are seen. $\langle$ Table $2>$ is the summarization of figurative attributes and universal features of the world's four high religions' costumes.

\section{The Universal Aesthetic Value of Religious Costume}

The belief system of each religion is expressed in the religious costume, which is one of ritual action for fulfilling the wish, yearning for the ideal life. The belief systems of the world's four high religions are respectively different. However the solemnity, sublimeness, cleanness, and frugality of each religion are expressed as a similar figurative result. This leads to the world's four high religions, sharing some common features of non structural formlessness, affluent silhouette, little decoration, and dull color. In this sense, they have the visual universality of wholeness type and clarity.

The aesthetic value of world's four high religions can be summarized with the three distinctive aesthetic values; 'The beauty of concealing', 'The beauty of chastity', and 'The beauty of nature', even though they have a little difference.
The religious costume of all four high religions clearly show 'The beauty of concealing' without revealing the line of the body under the influence of the religious absolute and chastity. 'The beauty of concealing' is not confined to the religious costumes but is extended to the costume of ordinary people who have the strong religiosity. The beauty of chastity is the aesthetic value that appears in the costume of monotonous form due to religious solemnity and sublimeness but not a gay color and decoration. In addition, the 'beauty of nature' is equally shown in the several religious costumes that have the natural silhouette, which is the type of affluent drapery and the form of wrapping or wearing the unstitched cloth. <Table 3> below is the summarization of universal aesthetic values that appear in the religious costumes of world's four high religions.

\section{Conclusions}

The religious costumes of the world's four religions have a variety of figurative attributes according to the different belief systems and their individual environment. The decoration is restrained in the Buddhist costume with rich silhouette and single colors 
Table 3. Aesthetic Value of World's Four High Religions' Costumes

\begin{tabular}{|c|c|c|c|c|}
\hline Items Religion & Buddhist costume & Hindu costume & Islam costume & Christian costume \\
\hline \multirow[t]{2}{*}{$\begin{array}{l}\text { Aesthetic } \\
\text { Values }\end{array}$} & $\begin{array}{l}\text { - Formlessness, Non artifi- } \\
\text { ciality, non decoration } \\
\rightarrow \text { The Beauty of the } \\
\text { Void } \\
\text { - Richness of whole type, } \\
\text { concealing the body } \\
\rightarrow \text { The Beauty of Con- } \\
\text { cealing } \\
\text { - Non structural change- } \\
\text { ability and color } \\
\rightarrow \text { The Beauty of Nature }\end{array}$ & $\begin{array}{l}\text { - The changeability of non } \\
\text { structural drapery } \\
\rightarrow \text { The Beauty of Nature } \\
\text { - Richness of whole type, } \\
\text { concealing the body } \\
\rightarrow \text { The Beauty of Con- } \\
\text { cealing } \\
\text { - Limited symbol and dec- } \\
\text { oration } \\
\rightarrow \text { The Beauty of Chas- } \\
\text { tity }\end{array}$ & $\begin{array}{l}\text { - The strict control of form } \\
\text { and body } \\
\rightarrow \text { The Beauty of Con- } \\
\text { cealing } \\
\text { - The changeability of non } \\
\text { structural formlessness } \\
\rightarrow \text { The Beauty of Nature } \\
\text { - Monotone and Non deco- } \\
\text { ration } \\
\rightarrow \text { The Beauty of Chas- } \\
\text { tity }\end{array}$ & $\begin{array}{l}\text { - The expression of the } \\
\text { absolute and verticality } \\
\rightarrow \text { The Beauty of So- } \\
\text { lemnity } \\
\text { - Richness of whole type, } \\
\text { covering the body } \\
\rightarrow \text { The Beauty of Con- } \\
\text { cealing } \\
\text { - Limited symbol and dec- } \\
\text { oration } \\
\rightarrow \text { The Beauty of Chastity }\end{array}$ \\
\hline & \multicolumn{2}{|l|}{$\downarrow$} & $\downarrow$ & $\downarrow$ \\
\hline \multirow[t]{2}{*}{\begin{tabular}{c|} 
Universal \\
Aesthetic Values
\end{tabular}} & \multicolumn{4}{|c|}{ The Beauty of Concealing / The Beauty of Chastity / The Beauty of Nature } \\
\hline & \multicolumn{4}{|c|}{$\downarrow$} \\
\hline Discussion & \multicolumn{4}{|c|}{$\begin{array}{l}\text { The expression of belief on the supernatural world and its recognition. } \\
\text { The ritual expression of means or procedures for fulfilling the wish of ideal life }\end{array}$} \\
\hline
\end{tabular}

such as gray and red. Non structural unstitched clothes based on the cosmology of Hinduism are the most distinctive in the Hindu costume in which symbols such as white, yellow, and red appear. The Islam costume, emphasizing the chastity takes on the closed forms, concealing the body. Meanwhile, the religious costume of the Christianity that sticks to the tradition expresses the beauty of solemnity by emphasizing the verticality and represents the symbolic meaning through the decoration and color.

In spite of the difference in the formality of the religious costumes of world's four high religions, figurative universality exists as followings: First, non structural feature in the composition, form, and wearing method of clothing appear in all religious costumes, second, rich silhouette using the drapery that covers the body, third, the restraint and suppression of decoration, and fourth, the preference of achromatic color and mono ton that implies the solemnity and sacredness. 'The beauty of concealing', which is the universal aesthetic value of religious costume, caused by the emphasis of religious absoluteness and chastity, distinctively appear in the world's four religions. In addition, while decoration and design are seen to be inhibited and limited in each religious costume, 'The beauty of chastity' is in common in the limited single color or achromatic color. 'The beauty of nature' appears in the natural drapery of rich costume and non systematic and asymmetric features.

Human beings pursue for the essential things through religion and inhibit desire. They also endeavor to contact divine beings by concealing the body. In this sense, religious costume is the expression of belief about the supernatural and disparate world and the personified beings in this kind of world, and the ritual action, performing its function as measures or procedures to fulfill the ideal life in the future. The forms of concealment and chastity are reflected in the usual costumes, affected by religion as well as religious costume.

\section{References}

Bellett, G. (2006, June 3). Five heed the call. The Vancouver Sun. Retrieved April 12, 2009, from http://www.canada.com/

Bhandari, V. (2004). Costume, textiles and Jewellert of India. New Delhi: Prakash Book Depot.

Bhandari, V., \& Dhingra, S. (1998). Textiles and craft of India. New Delhi: Prakash Book Depot.

Burton, R. F. (2004). Personal narrative of a pilgrimage to Al Madinah and Meccah. Wikisource. Retrieved March 17, 2009, from http://www.en.wikisource.org/

Cho, S. Y. (2005). Religion and culture, encountering in India. Seoul: Minsokwon.

Datta, J. G. (2006, June 3). Shani puja on shani trayodashi day 
22 July 2006. Datta Peetham Welcomes You. Retrieved April 12, 2009, from http://www.dattapeetham.com/

Ethiopian Orthodox Priest. (2008). Flickr. Retrieved March 23, 2009, from http://www.flickr.com/

Fallding, H. (1974). The sociology of religion. New York: McGraw-Hill.

Kim, H. S. (1993). A study on the symbols of ritual dress in Korean catholic church. Journal of Costume Culture. 1(1), 69-80.

Kim, K. K., Cho, J. M., \& Nam, M. W. (1999). The impression of on Korean catholic priest's ritual dress. Journal of the Korean Society of Clothing and Textiles, 23(5), 703-714.

Kim, Y. D. (2002). The ecological study in buddhism, folk customs, and environment. In Asian comparative folkore society (Ed.), Folk costumes and environment (pp. 139164). Seoul: Minsokwon.

Kwon, Y. S., \& Cho, W. H. (1997). A study on the symbolism of religious costume of India. Journal of the Korean Society of Clothing and Textiles, 21(4), 677688.

Leslie, J. (1992). The significance of dress for the orthodox Hindu woman. In R. Barnes \& J. B. Eicher (Eds.), Dress and gender making and meaning in cultural context (pp. 198-213). Oxford: Berg Publishers.

Lim, Y. J. (1990). A study on the religious costume in Korea. Costume, 14, 63-73.

Park, E. M. (2008). What is religion?: The philosophy of religion. Seoul: Arumnamu.

Razi, S. (2006, November 13). Clearing up misconceptions of Islam. Muslim Unity. Retrieved April 12, 2009, from http://www.smma59.wordpress.com/

Religion. (2008). Cambodia. Retrieved April 12, 2009, from http://www.angkor-wat-net.com/

Ross, H. C. (1985). The art of Arabian costume: A Saudi Arabian profile. Fribourg, Switzerland: Arabesque.

Seo, B. H., \& Kim, M. J. (2007). A study on the mechanism of religious symbol, manifested in costume-Focusing on the rites of high religion-. Journal of the Korean Society of Clothing and Textiles, 32(6), 935-946.

Smart, N. (1983). Worldviews: Cross-cultural explorations of human beliefs. New York: Scribner's.

Smith, H., Tickle, P., Armstrong, K., \& Gattuso, J. (2006). Talking to God: Portrait of a world at prayer. Milford, NJ: Stone Creek Publications.

Tea making ritual to the memory of a deceased monk. (2007, November 27). Bulgyo Today. Retrieved March 25, 2009, from http://www.bulgyotoday.com/

The Korea church history institute. (2001). Kim Su Hwan. Seoul: Jungmunsa.

Yamaori, T. (2004). The world's religions (G. S. Lee, Trans.). Seoul: Seoul Munhwasa. (Original work published 2000)

Yang, C. S. (2008). World religion and christianity. Paju: Korea Academic Information.

Yun, J. G. (1993). The aesthetics of the east. Seoul: Dungji.

\section{요 약}

세계의 여러 종교들은 각기 다른 믿음체계를 바탕으로 다양한 체계를 갖추고 있으며, 종교적 의미의 표 현인 종교복식 역시 종교별로 각기 다른 형식을 띠고 있다. 그러나 본 연구는 인류의 다양한 종교복식에 서 나타나는 보편적 특징을 연구하는데 목적이 있다. 종교는 그 범위가 불분명하고, 연구의 한계성이 분 명하므로 본 연구에서는 세계 4대 고등종교를 대상으로 연구한다. 본 연구의 목적은 첫째, 세계 고등종교 에 대한 고찰, 둘째, 종교복식에 나타난 조형적 특징 연구, 셋째, 종교복식에 나타난 보편적 조형미와 미 적가치에 대한 연구 및 논의 등이다. 세계 4대 고등종교의 종교복식에는 조형적 보편성이 존재한다. 첫째, 구성과 형태, 착장법 등에서의 비구조적 특징, 둘째, 인체를 감싸는 풍성한 실루엣, 셋째, 장식의 절제와 억제, 넷째, 무채색계열의 선호와 모노톤의 특징 등이다. 종교복식의 보편적 미적가치로는 종교적 절대성 과 정숙성 등으로 인한 '감춤의 미', 장식이나 문양 등의 억제와 단조로운 색상 등에서 '절제의 미' 그리고 드레이퍼리와 비구조적인 특징에서는 '자연의 미'가 나타난다. 인간은 종교를 통해 본질적인 것을 추구하 고 인체를 은폐함으로써 신성한 것과 접촉하려고 한다. 종교복식은 초자연적 타계와 믿음에 대한 표현이 며, 의식의례 행위이다. 각 종교의 종교복식은 물론 종교의 영향을 받은 복식에도 이러한 감춤과 절제의 형식들이 고스란히 반영되어 있다. 